George DAVID*

Ion CHICIUDEAN*

\title{
Golden reputation wanted for a gold producer. The case of the Rosia Montana Gold Corporation
}

\begin{abstract}
Inappropriate stakeholder communication often generates risks or even dangers to the organizations which are not aware of the importance of a proper flow of information to/from its publics.

"Rosia Montana Gold Corporation", a Canada-based company specialized in gold extraction, has initiated since 1996 a project to extract gold from the perimeter Rosia Montana (Western Carpathians, county of Alba, Romania). Although the technical documentation has been submitted back in 2004 to the authorities to be endorsed and approved, the approval is still pending due to a great amount of negative public perceptions often turned to hostile behaviors. In order to diminish this hostility, the company has started a huge communication campaign founded on factuality in its attempt to extract gold in Romania. However, the results are still unsatisfactory, even if the amount of negative perceptions has been lowered in a certain measure. In our paper we would like to analyze, based on the Situational Crisis Communication Theory (SCCT) and quantitative analysis methods, several influences produced by the organizational communication done so far over the organization itself, as well as over stakeholders such as the local community in Rosia Montana, public institutions, and non-governmental organizations.
\end{abstract}

Keywords: crisis management, crisis prevention, crisis communication, stakeholder perceptions, SCCT.

\section{Introduction}

Organizational reputation, regarded as one of the strategic intangible resources of any organization, is also the most sensitive to the threats concerning the functions of the organization, whether those threats come from inside or outside the organization. Any affect of organizational reputation may entail significant negative consequences on the other resources (material, financial, human, technological, etc.), and these consequences are often manifested on medium and long term.

Therefore, preserving, strengthening and defending organizational reputation must be a key concern of the management. Managers must be aware of both the importance of reputation and the role of communication actions in the effective management of reputation: the perceptions of organizational stakeholders - be they from outside or inside - perceptions which ultimately generates organizational reputation, can be properly managed especially through communication actions, and hence the role of communication in the protection of reputation.

In this idea, a trend has been noticed in the last decade: organizations tend to involve more their stakeholders in their actions and decisions, to listen more intensely their opinions as

* College of Communication and Public Relations, National University of Political Studies and Public Administration, Romania, george.david@comunicare.ro, ion.chiciudean@comunicare.ro. 
well as to engage themselves in solving social issues of the communities within which they operate, because managers have realized how much stakeholders can influence the smooth running of any business. At the same time, the concern of organizations to manage stakeholder reactions has become obvious. The management of stakeholder reactions during certain events with negative consequences includes, according to the vision of Timothy Coombs, communication efforts to influence how stakeholders perceive the situation, the organization in need, and the organization's response during this situation (Coombs \& Holladay, 2010). The importance showed in organizations to the good management of stakeholder reactions comes from the fact that the way stakeholders perceive the organization has become a crucial factor in the consolidation of its reputation. Moreover, stakeholders have a number of expectations from a company: they want it to continuously provide relevant and honest information about its actions, they desire to take part in some decisions concerning the organization, but, the most important, they need a powerful organization that they can trust and whose voice is listened in their community. Anthony Davis points out, in this respect, to a number of reasons for which organizations should constantly communicate with their stakeholders. One of the main reasons consists in the public confidence, which "provides companies a warranty over their functionality, in other words, stakeholders must be on their side to optimize organizational performance" (Davis, 2008, p.174).

The relationship between an organization and its stakeholders is one of interdependence, therefore, the organization can affect stakeholders, and these in turn may jeopardize the subsistence of an organization. This relationship depends on the importance of each of the stakeholders for the organization. The more important and valuable the involvement of a stakeholder in the organizational life, the more the stakeholder will have a strong influence on organization. Based on the level of stakeholder influence, Timothy Coombs separates them in primary and secondary. Primary stakeholders are "those people or groups that can be both harmful and beneficial to the organization" (Coombs \& Holladay, 2010, p. 20). The author mentions that, if organizations do not maintain effective communication with their primary stakeholders, this can lead to organizational failure or even to bankruptcy. Organization's primary stakeholders may stop its activity and initiate a crisis. Secondary stakeholders, seen by Coombs as influencers, can influence or be influenced by the company, but they "cannot stop the organization from its functioning, but can cause damage to the organization" (Coombs \& Holladay, 2010, p 20).

We can thus conclude that stakeholders can harm the organization, but they can also bring benefits, especially in difficult times, when the organizational image and reputation are in deadlock. In this respect, Kathleen Fearn-Banks (2007, p. 8) asserts that "favorable stakeholder relationships of an organization are beneficial during crisis management". Although the establishment of good stakeholder relations will not help the organization to prevent any unwanted situation, managing their reactions may have a crucial role in how the organization will address this situation and manage its credibility and reputation in the public arena.

The development of the online environment, particularly of the social networks, has resulted in the expansion of the list of stakeholders of a company and of the ways in which they can influence organizational reputation. Companies should be aware that, in the online environment, publics may come up to support and promote their work but, at the same time, these publics can seriously affect organizational credibility and reputation. Therefore, "the identification of both real-world and online stakeholders" (Cismaru, 2009, p. 85) is required as a prerequisite for the effective management of the company's reputation, as well as to systematically maintain good stakeholder relationships. 
Of course, the management of special situations, like the crises organizations may face, requires special approaches of the communication strategies, generally known as crisis communication. Both theorists and practitioners suggest a large number of approaches to this relationship between organizational reputation and crisis communication. For our case study, we will particularly make use of the Situational Crisis Communication Theory (SCCT) proposed by W. Timothy Coombs in 1995 and further developed by both the author and other researchers (see, for example, the collaboration between Coombs and Sherry Holladay; AnSofie Claeys, Patrick Vyncke \& Verolien Cauberghe (2010); Sora Kim \& Liu Brooke Fisher (2012); Hilary Fussell Sisco (2012); Skye Cooley \& Amy Jones (2013) and others).

\section{Literature review}

If one accepts the idea of the consequences of stakeholder perceptions, attitudes and actions on the organizational reputation, then one must also accept that reputation management is an important component of the company's top management. The way stakeholders perceive events which the organization faces may produce major influences over its image and reputation. Information about the organization that reaches its stakeholders will influence the way how they perceive the events and their relationship with the organization. The foundation of effective stakeholder relationships, as an important way of achieving and maintaining organizational reputation, is built in time, before the onset of any difficulties and negative events. If this is not done, stakeholders may lengthen these events, may increase the difficulties and can aggravate their consequences. However, effective communication with them, through thoughtful communication strategies and actions, can turn the stakeholders into real advocates of the organization, offering support and resources to reduce the negative effects of events at both the physical (human losses, property damage, loss of markets, boycotts of products and services and so on) and the symbolic level (outcomes affecting image and reputation).

The complex environment in which organizations operate today requires a comprehensive approach of their image and reputation. Thus, a growing interest from various social instances, more and more diverse and active, comes out and progressively evolves, regarding the malfunctions that may appear during the activities of a company; moreover, these instances investigate their causes, how they have occurred, their manifestations and consequences. This pattern fits to all contingencies (crises included) affecting through their development and consequences both stakeholder perception and image and reputation of organizations.

Approaching the organizational image and reputation requires an internal logic and the observance of certain epistemological compliance regarding their coherence and consistency. Thus, from a chronological point of view, a company must have the gain of awareness (notoriety) among its primary goals. Awareness is key to the organization's image. Creating and consolidating awareness is the first step in the image building process (Chiciudean \& David, 2011). Therefore, the organization must "be present in the public mind as quickly as possible" (Libaert, 2009, p. 116) in order to benefit this way from a good image. Bernard Dagenais also points out the importance of awareness while building the image of an organization: "It sometimes happens that the company believes it has a positive image to its public, although it actually does not even have notoriety and therefore much less image. Before making itself loved, a company must be known, so it must have acquired a certain notoriety" (Dagenais, 1998, p. 123). Once the image created, based on a consistent notoriety, organiza- 
tional reputation arises as well. The concept of reputation implies a gradual evolution over time, evolving as long as the social actors involved acquire and share among them a stable image of the organization; this image reflects, in large part, the company's capability to confirm their expectations and even exceed them. All these actions are part of a complex process involving substantial efforts of professional reputation management (Coman, 2009).

Reputation consists in an aggregate of beliefs or judgments about a particular company, existing among the public. One can state that a company is reputable when actors involved have information about the quality of its management, its substantial financial income, innovation, marketing, products and services, activities, corporate social responsibility campaigns (Coman, 2009). Reputation components become visible over time, in conjunction with the attitudes, beliefs and positive opinions of stakeholders on the company. The various audiences, ranging from shareholders and employees to consumers, investors and the media, follow certain functionality and organizational behavior variables before investing their trust in the company (O'Connor, 2005). Starting from the idea that reputation is a general assessment made by stakeholders following criteria and factors that come up over time and know a certain dynamic, depending on their needs, interests, aspirations and expectations as well as on the context, Fortune magazine, who has created and imposed "Fortune corporate reputation index", has ranked the most reputable companies in the U.S., based on eight indicators: effective management, high standard products and services, financial stability, vision on employing and keeping capable people, use of corporate assets, the mission of creating values and investing in them, innovation, corporate social responsibility (Oliver, 2009, p 52).

The elements of corporate reputation rating, as a result of the evolution of stakeholder expectation horizons, of the social, economic and scientific-technical context, can overlap on and/or can be contaminated by traditional elements, which can lead to a bad, diffuse and contradictory reputation. Therefore, the concerns of experts to set up clear and rigorous criteria to assess reputation are useful. In this respect, there is a certain consensus on a package of seven indicators that should be looked up in a company and signal a high reputation: the ability to use financial resources, the conduct towards employees, the social responsibility, the commitment to customers, quality products and services, performant management, good communication (Lee, 2004). Hence the fact that the reputation of the organization depends on its ability to communicate, to speak out everything relevant and of interest to stakeholders, so that reputation could play the role of a recorded tape about the company, playing inside the minds of the receivers (Cameron \& Wilcox, 2007). The stakeholder collective mind is this way the holder and the evaluator of the corporate reputation, therefore a good reputation may be built or destroyed by everything the organization does: from how they treat their employees to how they manage their conflicts with the external environment (Haines, 2008).

Reputation cannot be solely seen as the result of the organization's success in the market. It is built over time and is strongly influenced by how companies cope with various crises. The attribution theory and the situational crisis communication theory reveal the consequences over organizational reputation produced by certain crisis intensifiers: consistency (history of crises in the organization, the probability that the organization may have been faced such crises in its past) and distinctiveness (the relationship between history and previous reputation, how well or badly the organization treated its organizational actors in similar situations) (Coombs, 2007). If the organization had dealt with similar events in its past and had behaved inappropriately towards stakeholders throughout its history, its reputation would be damaged, because the organizational actors can leave their relationship with the organization and may 
generate negative discourses (Coombs, 2007). In this situation, sometimes extremely critical for the organization, the management must prevent, through communication strategies and an appropriate content of crisis communication, these two effects proved to be potentially negative for the organization's reputation.

The crisis analysis from the perspective of its intensifiers reveals that each type of crisis generates specific amounts of organizational responsibility for the crisis event. It highlights three specific situations with different consequences over the reputation, depending on the amount of responsibility that is assigned to the organization for each type of crisis: the "victim" category is weak in terms of assigning organizational responsibility for the crisis (natural disasters, workplace violence, poor products, rumors), and the organization is seen as a victim of events; the "accidental" category involves a minor allocation of responsibility for the crisis (accidents due to technical errors, harmful products due to technical errors), and the event is considered random and uncontrollable by the organization; the "intentional" category involves large allocations in terms of crisis responsibility (accidents caused by human error, human errors or harmful products due to organizational errors) and the event is considered as intended (Coombs, 2007). By identifying the amount of responsibility assigned for the crisis, organizations can early determine and describe the consequences of the crisis over their own reputation. Therefore, these intensifiers substantially influence the process of building crisis response strategies, which vary depending on the acceptance / non-acceptance by the organization of a certain responsibility for the crisis. The approach suggested by Coombs approach for such situations is as follows: "as long as threats to reputation and negative effects grow up, crisis managers should use the crisis response strategies fitted to the level of responsibility showed by the crisis. In other words, crisis managers should accept higher degrees of responsibility as reputational threats intensify" (Coombs, 2007, p.138).

Media stands out as an active factor in the process of building organizational reputation. More and more often media change the order of the organizational priorities forcing managers and communication specialists to grant them strategic importance. Moreover, the media impose certain standards on the behavior of an organization (Chiciudean \& David, 2011). These standards, imposed by the media in the communication sphere, are acquired and used by the actors of this sphere, becoming evaluation criteria of the overall organizational behavior, with important consequences on perceptions about organizations, on their image and reputation. Serious deviations from these standards, especially in crisis situations, will not only be publicly disapproved, but they will also be penalized by journalists, who will blame the organization, will get involved in investigations of any adverse situations, will increase the perceived danger of facts, and will require drastic punishment to the organization. Reputational consequences are obvious. That is why, the organizational behavior should reflect accountability, openness and transparency.

Mass media have an important asset. They have control over how the organization's stakeholders will perceive negative events, as they are the public opinion influential and the most credible source of information. The way the media perceive the crisis faced up by an organization is crucial because they establish, in most cases, the direction and the meaning of the events, thus directing public perceptions, because "in a mass society, the first impression of a reporter is already reality" (Chiciudean \& Țoneș, 2010, p 128). Often, managers running the crisis resolution are busy trying to assess the situation and taking emergency measures, not giving due attention to journalists, so that those will seek information elsewhere or will position themselves against the steps taken by the organization. Ignoring journalists during 
crisis management "proves to be a catastrophic thinking error [...] that organizations facing a difficult situation often make and that can become disastrous" (Regester \& Larkin, 2003, p.157). Disastrous, of course, from the perspective of public perception, of the allocation of crisis responsibility, of the threats and negative consequences over organizational reputation.

Mass media are a public memory enhancer. They use databases allowing to accurately determine whether organizations have been dealing with similar events in their past, whether there have been errors in their behavior and attitude to the victims, to the press and other actors involved in the event. Media can affect this way the organizational reputation not only by a hostile attitude and the way they cover ongoing events, but also by reminding past events and actions with negative meanings in the public mind. In the circumstances of the use of new technologies, that can store huge amounts of information and can generate interactions "from an end of the world to the other" (Wolton, 2012, p. 22), these issues may increase and worsen. Therefore, managers need to rethink how they intend to address the events that may affect the reputation of their organizations. This rethinking "can lead to methods very different from classical procedures recommended by the followers of traditional solutions" (Chiciudean \& David, 2011, p 183).

\section{Case study}

Brief history. In the broader context of political, social and economic change in Romania after 1990, some strategic decisions were taken regarding the suspension or even the end of exploitation of mineral resources by the state; those who have had a substantial impact on Romanian public opinion concerned mining coal and gold. Such a particular decision has resulted in the closure of the gold mines in the perimeter Rosia Montana, a gold zone located in the Apuseni Mountains of western Romania, where gold mining tradition is documented since 131 A.D., and the area is still dependent on gold mining.

In 1996, Gabriel Resources, a company headquartered in Toronto (Canada), has showed its interest in resuming mining in the area. As a result, in 1997, the company Eurogold Resources SA has been established, renamed later, in 2000, Rosia Montana Gold Corporation (RMGC), with the object of extracting gold and other minerals in the mentioned area and whose shareholders have been Gabriel Resources $(80.46 \%)$ and the Romanian state, through the company Minvest Deva (19.31\%). Between 1997 and 2002, while conducting specific legal procedures, RMGC performed geological explorations to determine the quantities of existing ore; these explorations showed that the Rosia Montana gold deposit was practically the largest in Europe, hence resulting the special interest towards this project.

In December 2004, RMGC submitted to the Environmental Protection Agency of the Alba County a request for the environmental permit to start the operation. The request was then step-by-step forwarded up to the highest hierarchical level of the state administration, i.e. the Romanian Government. Because of the importance of the deposit in Rosia Montana, this economic issue has quickly turned into a political one; public perception - either Romanian or international - regarding the environmental danger of gold mining by using potassium cyanide has also substantially contributed to this transformation: the danger suggested by this substance has generated a strong wave of public adversity since the very beginning of the project. Given the effervescence of the Romanian political scene and the hostility of a part of public opinion, the approval of commencement of mining has become a "hot potato" for all policy-makers 
since 2004 to present, no matter if they were in power or in opposition, so this decision was avoided for nine years.

In terms of organizational communication, between 2004 and 2007, along with steps taken to start the operation, RMGC performed a communication campaign having the local community as the main target, because the major interest of the company at that time consisted in purchasing the land within the gold perimeter, project which implied two other projects as well: the relocation and resettlement of residents who had agreed to sell their land. The efforts to counter the hostile messages of various social actors (media outlets, NGOs, public institutions, academic bodies, representatives of civil society, actors of the political scene, opinion makers, etc.) were not very evident in this period of time; as a result, the attacks on RMGC's reputation have been favored by good conditions as far as the organizational response has been concerned and therefore pushed the company into a crisis that is still ongoing.

Between 2007 and 2009, RMGC tried to diminish the effects of this attack by a consistent set of functional messages, consisting of facts meant to speak by themselves about the company and about the mining project. Consequently, extensive and costly actions have been undertaken to demonstrate the compliance to all claims made by institutions involved in approving the project, with the hope that a solid, documented plan, based on tangible resources, etc. would speak by itself about the company's positive attitude and behavior in approaching this project. However, the results of this behavior have not been those expected by the company, so that the crisis has taken a new dimension in its depth.

Realizing finally the role of communication in managing this situation, as well as of the strategic approach to communication, RMGC has been developing since 2009 a communication campaign intended to change public perceptions in favor of the project and reduce the hostility of the attitude of organizational stakeholders. Based on the information we have got so far, we consider it the most extensive and expensive communication campaign carried out so far by any organization performing in the Romanian business environment. The result of this approach is beginning to produce results: part of media reports and, consequently, public perceptions on this project have changed in favor of RMGC; thus, for example, according to a survey published in February 2012 (IRES, 2012 , p. 28-35), which refers to two simultaneous events of 28 January 2012 - one against the project, organized in Bucharest and one in favor of it, held in Rosia Montana - pros and cons are balanced, but slightly favorable to the mining project: in the circumstances that respondents found out in quite equal proportions about the two events (28\% and respectively $27 \%$ ), $57 \%$ of them agreed to the support meeting in Rosia Montana, while $43 \%$ agreed to the opposition demonstration in Bucharest.

This empirical observation has also been confirmed by other information. Thus,

"according to data provided by the company, $[\ldots]$ there have been measured partial outcomes such as:

- since 2008 to 2010 the total number of media reports on the Roşia Montană project has grown up to 4 times, thus showing the media awareness on this topic; the media awareness has grown up primarily as a results of publicity campaigns (with an informational component instead of advertising), which acted like a 'trigger' for editorial columns;

- the percentage of positive media reports has doubled, that of negative ones has halved, and the percentage of neutral reports has grown up with $40 \%$;

- according to monthly and annual studies made by IMAS (a Romanian opinion polling institute) between 2008 and 2011, approximately one third of the public opinion is in favor 
of the project, another third is against, and the remaining others still do not have a clear attitude. That means there is no dominant opinion at the level of general public;

- more than 100,000 'RMGC friends' on Twitter in August, 2011" (David \& Chiciudean, 2011).

Moreover, there are indications that now, due to a governmental attitude favoring the exploitation of natural resources, RMGC has reduced the reactive approach to its communication campaign in favor of a more proactive one, designed to build positive attitudes, not only to change the negative ones.

Research questions. In our opinion, the above-described situation is an obvious case of organizational crisis, because

"being unable to start the project after nine years from the submission of the request to start operation has produced extremely important consequences for the organization:

- the company has had economic losses. According to the most recent fiscal audit submitted to the Ministry of Finance - that for the year 2011 - they exceed RON 160 million (about EUR 37 million). Comparable amounts were reported in the previous years: approximately RON 163 million loss in 2009, about RON 165 million loss in 2010;

- the communication flows with certain stakeholders (State institutions, media outlets, think tanks, opinion leaders, non-governmental organizations, national public opinion) have been blocked or altered;

- the Romanian political scene still shows controversial positions with regard to the project: while President Băsescu strongly supports the project, the Prime Minister Victor Ponta, as well as Rovana Plumb, the current minister of Environment, showed in the recent past their open opposition to it, opposition somewhat softened after the government takeover;

- although hostile attitude towards the project has somewhat diminished its intensity in the last 4 years, there are still stakeholders whose negative feelings about this project affect the RMGC corporate image, producing influences on public perceptions. Among them: the Romanian Academy, the Soros Foundation, Alburnus Maior, the weekly Formula As;

- some vocal environmental organizations, such as Greenpeace, have involved themselves as opponents of the project, thus putting into question the reputation of RMGC" (David, 2013).

An important consequence of these developments consists in the negative effects over $R M G C$ 's reputation to such an extent that, in a certain period of time (2007-2009), the mining project was regarded as impossible and, therefore, the purpose of the organization was completely compromised. At that time, the management has decided to initiate the abovementioned communication campaign in order to preserve and restore organizational reputation, which, being badly affected, was producing negative effects on the other types of organizational resources.

In order to understand to what extent reputation influences the proper development of the organizational functions, we must specify first that reputation is built and developed mainly due to the change of messages between an organization and its stakeholders as well as between the latter ones. Essentially, there are two types of messages: functional, consisting in the actual facts of the organization (productivity, product quality, etc.) or resulting from such acts (turnover, profit, equity etc.); deliberate, consisting in what the organization intentionally says about itself and its actions, as well as what others say about it. The credibility of functional messages is great because those who perceive directly the organization also perceive "by their own senses" what it does; unfortunately, audiences that receive and interpret such messages are limited, because there are few people getting direct contact with the organization and with 
deeds. Therefore, the organization must also design and deliver deliberate messages, meant to show to much larger audiences, most often through media, its achievements.

To verify the truth of the above statement, we have devised the following empirical research questions:

Q1: While managing an organizational crisis, are the functional messages (organization's deeds) enough to ensure the preservation of reputation?

Q2: To what extent the functional messages of an organization facing a crisis can generate stakeholder attitudes and behaviors regarding the organization?

Q3: Which is the role of the deliberate messages (organization's statements) in the effective management of an organizational crisis?

Data and methods. In order to get answers to the above-formulated research questions, we issued an online survey on an unstructured sample; it was available to respondents between February 11 and May 11, 2013 and 149 valid responses have been recorded. The demographic structure of the sample is described in the Tables 1-2 below:

Table 1. Sample structure by age.

\begin{tabular}{|l|l|c|c|c|c|}
\hline & & Frequency & Percent & Valid Percent & Cumulative Percent \\
\hline Valid & $18-25$ years & 79 & 53.0 & 53.7 & 53.7 \\
\hline & $26-35$ years & 34 & 22.8 & 23.1 & 76.9 \\
\hline & $36-45$ years & 24 & 16.1 & 16.3 & 93.2 \\
\hline & $46-55$ years & 4 & 2.7 & 2.7 & 95.9 \\
\hline & $56-65$ years & 5 & 3.4 & 3.4 & 99.3 \\
\hline & Over 65 years & 1 & .7 & .7 & 100.0 \\
\hline Missing & Total & 147 & 98.7 & 100.0 & \\
\hline Total & System & 2 & 1.3 & & \\
\hline
\end{tabular}

Table 2. Sample structure by education.

\begin{tabular}{|l|l|c|c|c|c|}
\hline \multicolumn{2}{|l|}{} & Frequency & Percent & Valid Percent & Cumulative Percent \\
\hline Valid & & 2 & 1.3 & 1.3 & 1.3 \\
\hline & High school student / graduate & 9 & 6.0 & 6.0 & 38.9 \\
\hline & College student & 32 & 21.5 & 21.5 & 60.4 \\
\hline & Undergraduate & 17 & 11.4 & 11.4 & 24.2 \\
\hline & Master student & 54 & 36.2 & 36.2 & 96.6 \\
\hline & Graduate & 17 & 11.4 & 11.4 & 12.8 \\
\hline & Doctoral studies & 5 & 3.4 & 3.4 & 100.0 \\
\hline & Doctor & 13 & 8.7 & 8.7 & 32.9 \\
\hline & Total & 149 & 100.0 & 100.0 & \\
\hline
\end{tabular}

No significant correlations have been found between these demographic indicators and respondent perceptions on the functional messages delivered by the company. 
Table 3 describes the measure in which respondents have appropriate knowledge about the mining project.

Table 3. Sample structure by the self-estimated degree of familiarity with the situation investigated.

\begin{tabular}{|c|c|c|c|c|c|}
\hline & & Frequency & Percent & Valid Percent & Cumulative Percent \\
\hline \multirow[t]{6}{*}{ Valid } & Totally unfamiliar & 10 & 6.7 & 7.0 & 7.0 \\
\hline & Familiar to a small extent & 57 & 38.3 & 39.9 & 46.9 \\
\hline & Neither familiar, nor unfamiliar & 44 & 29.5 & 30.8 & 77.6 \\
\hline & Familiar to a great extent & 24 & 16.1 & 16.8 & 94.4 \\
\hline & Very familiar & 8 & 5.4 & 5.6 & 100.0 \\
\hline & Total & 143 & 96.0 & 100.0 & \\
\hline Missing & System & 6 & 4.0 & & \\
\hline \multicolumn{2}{|l|}{ Total } & 149 & 100.0 & & \\
\hline
\end{tabular}

In order to get answers to Q1, we have considered several facts, either ongoing or already done by RMGC, as functional messages delivered by the company:

- the job offer;

- the support of the local sustainable development;

- the resettlement / relocation plan;

- the compliance with environmental regulations.

When it comes to the first functional message considered - the job offer - the mining project would create a significant number of jobs in an area where the unemployment rate is above the national average and where local people depend on gold mining for almost 2,000 years. According to the company (RMGC1), the project would generate a total number of 3,600 jobs. Asked about the role of this project in lowering the unemployment rate in the area, the respondents gave answers as follows (Table 4):

Table 4. The perception on the impact of the RMGC's job offer over the local unemployment rate.

\begin{tabular}{|l|l|c|c|c|c|}
\hline \multicolumn{2}{|l|}{} & Frequency & Percent & Valid Percent & $\begin{array}{c}\text { Cumulative } \\
\text { Percent }\end{array}$ \\
\hline Valid & Not at all & 8 & 5.4 & 5.5 & 5.5 \\
\hline & In a small measure & 47 & 31.5 & 32.4 & 37.9 \\
\hline & $\begin{array}{l}\text { Neither in a small, nor in a great } \\
\text { measure }\end{array}$ & 26 & 17.4 & 17.9 & 55.9 \\
\hline & In a great measure & 62 & 41.6 & 42.8 & 98.6 \\
\hline & $\begin{array}{l}\text { It will eliminate the local } \\
\text { unemployment }\end{array}$ & 2 & 1.3 & 1.4 & 100.0 \\
\hline Missing & Total & 145 & 97.3 & 100.0 & \\
\hline Total & & 4 & 2.7 & & \\
\hline
\end{tabular}


As one can see, the balance between skeptical and optimistic opinions is slightly favorable to the last ones: a total of 55 respondents believe that the project will not reduce the unemployment at all or just in a small measure, while 64 believe that it will reduce or even eliminate the local unemployment.

The second functional message refers to the potential support offered through this project to the local sustainable development. The answers are described in the Table 5 below:

Table 5. The perception on the support offered by the mining project to the local sustainable development.

\begin{tabular}{|l|l|c|c|c|c|}
\hline \multicolumn{2}{|l|}{} & Frequency & Percent & Valid Percent & Cumulative Percent \\
\hline Valid & Not at all & 31 & 20.8 & 21.4 & 21.4 \\
\hline & To a small extent & 50 & 33.6 & 34.5 & 55.9 \\
\hline & $\begin{array}{l}\text { Neither to a great, nor to a } \\
\text { small extent }\end{array}$ & 23 & 15.4 & 15.9 & 71.7 \\
\hline & To a great extent & 34 & 22.8 & 23.4 & 95.2 \\
\hline & Definitely yes & 7 & 4.7 & 4.8 & 100.0 \\
\hline Missing & Sotal & 145 & 97.3 & 100.0 & \\
\hline Total & & 4 & 2.7 & & \\
\hline
\end{tabular}

In this case, the respondents expressed more clearly their hesitation as to the sustainable consequences of the project, 81 of them showing themselves reluctant, while 41 gave credit to it.

The third functional message considered for this study regards the resettlement / relocation effort made by the company. Up to date, 125 families accepted the resettlement plan of the company, moving to a brand new neighborhood built by RMGC in the town Alba Iulia (RMGC2); for those who have chosen to relocate, the company has offered support and counseling. The perception of this functional message is illustrated in the Table 6 below:

Table 6. The perception on the RMGC's resettlement / relocation plan.

\begin{tabular}{|l|l|c|c|c|c|}
\hline \multicolumn{2}{|l|}{} & Frequency & Percent & Valid Percent & Cumulative Percent \\
\hline Valid & Very bad offer & 17 & 11.4 & 11.6 & 11.6 \\
\hline & Offer rather bad & 18 & 12.1 & 12.3 & 24.0 \\
\hline & Offer neither good or bad & 20 & 13.4 & 13.7 & 37.7 \\
\hline & Offer rather good & 86 & 57.7 & 58.9 & 96.6 \\
\hline & Very good offer & 5 & 3.4 & 3.4 & 100.0 \\
\hline Missing & Total & 146 & 98.0 & 100.0 & \\
\hline Total & & 3 & 2.0 & & \\
\hline
\end{tabular}


With 91 answers favoring the resettlement / relocation plan and 35 against it, we can conclude that there is a clearer perception of the functional message delivered by the company.

For the fourth functional message considered, in spite of the assurances given by the company as far as the project environmental safety is concerned (RMGC3), the perception on the potential environmental risks of the project has been measured, the results being as follows (Table 7):

Table 7. The perception on the environmental risk of the mining project $(1=$ no risk, 10 $=$ the highest risk).

\begin{tabular}{|l|l|c|c|c|c|}
\hline \multicolumn{2}{|l|}{} & Frequency & Percent & Valid Percent & Cumulative Percent \\
\hline Valid & 1 & 4 & 2.7 & 2.8 & 2.8 \\
\hline & 2 & 4 & 2.7 & 2.8 & 5.5 \\
\hline & 3 & 9 & 6.0 & 6.2 & 11.7 \\
\hline & 4 & 2 & 1.3 & 1.4 & 13.1 \\
\hline & 5 & 14 & 9.4 & 9.7 & 22.8 \\
\hline & 6 & 9 & 6.0 & 6.2 & 29.0 \\
\hline & 7 & 17 & 11.4 & 11.7 & 40.7 \\
\hline & 8 & 26 & 17.4 & 17.9 & 58.6 \\
\hline & 9 & 21 & 14.1 & 14.5 & 100.0 \\
\hline & 10 & 39 & 26.2 & 26.9 & \\
\hline Missing & Sotal & 145 & 97.3 & 100.0 & \\
\hline Total & System & 4 & 2.7 & & \\
\hline
\end{tabular}

As to the responsibility attributed to different entities involved in the project, the answers are as follows (Table 8):

Table 8 . The perception of the responsibility for the environmental risks of the mining project.

\begin{tabular}{|c|c|c|c|c|c|c|c|c|}
\hline & & 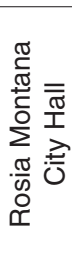 & 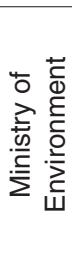 & $\sum_{\square}^{O}$ & 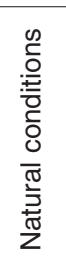 & 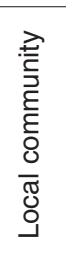 & 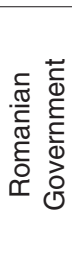 & 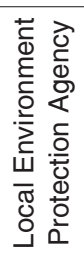 \\
\hline$N$ & Valid & 120 & 124 & 140 & 119 & 118 & 127 & 125 \\
\hline \multirow{6}{*}{$\begin{array}{l}\text { Valid } \\
\text { percent }\end{array}$} & Missing & 29 & 25 & 9 & 30 & 31 & 22 & 24 \\
\hline & No responsibility at all & 10.8 & 4.0 & 2.9 & 44.5 & 41.5 & 4.7 & 3.2 \\
\hline & Responsible to a small degree & 25.0 & 1.6 & 1.4 & 19.3 & 16.9 & 5.5 & 4.0 \\
\hline & $\begin{array}{l}\text { Responsible neither to a small, } \\
\text { nor to a high degree }\end{array}$ & 32.5 & 21.8 & 6.4 & 25.2 & 33.9 & 21.3 & 20.8 \\
\hline & Responsible to a high degree & 23.3 & 38.7 & 32.9 & 10.1 & 4.2 & 38.6 & 36.0 \\
\hline & Totally responsible & 8.3 & 33.9 & 56.4 & .8 & 3.4 & 29.9 & 36.0 \\
\hline
\end{tabular}


In this context, we must detail that a high degree of responsibility is attributed to RMGC (Table 9) - the entity perceived as the most accountable among those above-mentioned:

Table 9. The perception on RMGC's responsibility in case of an environmental accident.

\begin{tabular}{|l|l|c|c|c|c|}
\hline & & Frequency & Percent & Valid Percent & $\begin{array}{c}\text { Cumulative } \\
\text { Percent }\end{array}$ \\
\hline Valid & No responsibility at all & 4 & 2,7 & 2,9 & 2,9 \\
\hline & Responsible to a small degree & 2 & 1,3 & 1,4 & 4,3 \\
\hline & $\begin{array}{l}\text { Responsible neither to a small, } \\
\text { nor to a high degree }\end{array}$ & 9 & 6,0 & 6,4 & 10,7 \\
\hline & Responsible to a high degree & 46 & 30,9 & 32,9 & 43,6 \\
\hline & Totally responsible & 79 & 53,0 & 56,4 & 100,0 \\
\hline Missing & Sotal & 140 & 94,0 & 100,0 & \\
\hline Total & & 9 & 6,0 & & \\
\hline
\end{tabular}

However, no significant correlation has been found between the perception of risk and the organizational responsibility.

A correlation has been found between the job offer of RMGC (seen as reducing the unemployment rate in the area) and the company's resettlement / relocation project: Spearman's rho $=0.295$, a $<0.01$. In our interpretation, this correlation must be understood as follows: the higher the credibility of the job offer, the more the trust in the resettlement / relocation program.

To get answers to Q2, the respondents have been questioned about their potential to do something in favor or against the mining project: to take part in a public meeting or a protest march, to participate in a flashmob, etc.). the frequencies of the answers are as follows (Tables 10 and 11):

Table 10. The potential to take part in a support meeting.

\begin{tabular}{|l|l|c|c|c|c|}
\hline \multicolumn{2}{|l|}{} & Frequency & Percent & Valid Percent & $\begin{array}{c}\text { Cumulative } \\
\text { Percent }\end{array}$ \\
\hline Valid & Not at all & 25 & 16.8 & 17.1 & 17.1 \\
\hline & In a small measure & 27 & 18.1 & 18.5 & 35.6 \\
\hline & $\begin{array}{l}\text { Neither in a small, nor in a } \\
\text { great measure }\end{array}$ & 54 & 36.2 & 37.0 & 72.6 \\
\hline & In a great measure & 18 & 12.1 & 12.3 & 84.9 \\
\hline Missing & Sefinitely yes & 22 & 14.8 & 15.1 & 100.0 \\
\hline Total & Total & 146 & 98.0 & 100.0 & \\
\hline
\end{tabular}


Table 11. The potential to take part in a protest meeting.

\begin{tabular}{|c|c|c|c|c|c|}
\hline & & Frequency & Percent & Valid Percent & $\begin{array}{c}\text { Cumulative } \\
\text { Percent }\end{array}$ \\
\hline Valid & Not at all & 6 & 4.0 & 4.1 & 4.1 \\
\hline & In a small measure & 16 & 10.7 & 11.0 & 15.1 \\
\hline & $\begin{array}{l}\text { Neither in a small, nor in a } \\
\text { great measure }\end{array}$ & 42 & 28.2 & 28.8 & 43.8 \\
\hline & In a great measure & 37 & 24.8 & 25.3 & 69.2 \\
\hline & Definitely yes & 45 & 30.2 & 30.8 & 100.0 \\
\hline & Total & 146 & 98.0 & 100.0 & \\
\hline Missing & System & 3 & 2.0 & & \\
\hline Total & & 149 & 100.0 & & \\
\hline
\end{tabular}

Although there is no significant correlation between the two potential behaviors (pro or against), one can see that the intention to protest against the project is higher than that to sustain it. Moreover, the respondents are more passive as far as the support is concerned ( 52 would rather not participate, compared to 40 who would participate) and more willing to act in the case of a protest (22 rather not, compared to 82 who would agree). Indeed, a significant correlation has been found between the perception on the company's responsibility in case of an environmental accident and the availability to protest: Spearman's rho $=0.341, \mathrm{a}<0.01$.

When it comes to the answer to Q3, we would like to remind the company's statements about the outcomes of its communication campaign, made in 2011 and already cited above; thus, while the percentage of the positive media reports doubled, one third of the Romanian general public became favorable to the project.

\section{Conclusion}

Reputation is an organizational asset that requires a proper management and much attention; otherwise reputational losses may generate additional damage to an organization. Therefore reputation should be one of the crucial concerns of managers as they deal with crisis situations, because such situations produce high risks to this organizational resource.

The main threat addressed to reputation consists in stakeholder perceptions which can be affected by concern, worry, anger, fear. Or, one can manage perceptions especially through adequate communication strategies.

Delivering functional messages (doing things to be seen by stakeholders) is not enough, although their credibility is strong. As we have tried to demonstrate, RMGC's functional messages, such as creating jobs, supporting local sustainable development, resettling / relocation efforts, environmental care produced less result in the first phase of the project, when the organization hoped that "facts would speak for it". Once accompanied by deliberate messages (speaking out about the things done), the consequences of functional messages at the level of stakeholder perception have become more favorable to the company. 
Another conclusion as far as organizational reputation is concerned is that reputation should be perceived and managed in the larger social context including the organization facing a crisis. As already shown in the Table 8, the responsibility attributed to RMGC, although high, has been somehow shared among the entities considered for the study. This is an important consequence that must be kept into account while planning crisis response strategies aimed to defend organizational reputation.

Finally, another conclusion regards the stakeholder availability to behave in a certain way in the relationship with an organization perceived as accountable in a crisis. Thus, stakeholders are more open to participate in protests against such an organization than to support it.

\section{References}

Cameron, G. T. \& Wilcox, D. L. (2007). Public Relations: Strategies and Tactics. Boston: Pearson.

Chiciudean, I. \& David, G. (2011). Managementul comunicării în situații de criză (Communication Management in Crisis Situations). Bucharest: Comunicare.ro.

Chiciudean, I. \& Țoneș, V. (2010). Gestionarea crizelor de imagine (Image Crisis Management). Bucharest: Comunicare.ro.

Cismaru, D.-M. (2009). Comunicarea internă în organizații(Internal Communication in Organizations). Bucharest: Tritonic.

Claeys, A-S., Vyncke, P. \& Cauberghe, V. (2010). Restoring Reputations in Times of Crisis: An Experimental Study of the Situational Crisis Communication Theory and the Moderating Effects of Locus of Control. Public Relations Review, 36(3), 256-262.

Coman, C. (2009). Comunicarea de criză. Tehnici și strategii (Crisis Communication: Techniques and Strategies). Iași: Polirom.

Cooley, S. \& Jones, A. (2013). A Forgotten Tweet: Somalia and Social Media. Ecquid Novi: African Journalism Studies, 34(1), 68-82.

Coombs, W. T. (2007). Attribution Theory as Guide for Post-Crisis Communication Research. Public Relations Review. 33 (2), 135-139.

Coombs,W. T. \& Holladay, S. J. (Eds.). (2010). The Handbook of Crisis Communications. Singapore: Blackwell Publishing Ltd.

Dagenais, B. (1998). Le Plan de communication. Laval: Presses de l'Université de Laval.

David, G. (2013). An application of the situational crisis communication theory to investigate uncertainty existing in local communities. Article submitted to the Review of Research and Social Intervention.

David, G. \& Chiciudean, I. (2011). Factuality as a Crisis Communication Tool. Case Study: Roșia Montană Gold Corporation. Paper presented in the International Conference "Identity and Intercultural Communication", Bucharest, September, 2011.

Davis, A. (2008). Tot ce trebuie să știi despre PR (Everything You Need to Know about PR). Bucharest: Publica.

Fearn-Banks, K. (2007). Crisis Communication: A Casebook Approach. New Jersey: LEA.

Fussell Sisco, H. (2012). Nonprofit in Crisis: An Examination of the Applicability of Situational Crisis Communication Theory. Journal of Public Relations Research, 24(1), 1-17.

Haineș, R. (2008). Tipuri și tehnici de comunicare în organizații (Organizational Communication Types and Techniques). Bucharest: Universitară.

Kim, S. \& Brooke Fisher, L. (2012). Are All Crises Opportunities? A Comparison of How Corporate and Government Organizations Responded to the 2009 Flu Pandemic. Journal of Public Relations Research, 24(1), 69-85.

IRES (Romanian Institute for Evaluation and Strategies). (2012). Percepția agendei publice - săptămâna 2228 ianuarie 2012 (Public Agenda Perception - Week January 22-28, 2012). http://www.ires.com.ro/uploads/articole/ires_raport-de-cercetare-agenda-public\%C4\%83.pdf, retrieved on March 25, 2013.

Lee, B. K. (2004). Corporate Image Examined in a Chinese-Based Context: A Study of a Young Educated Public in Hong Kong. Journal of Public Relations Research, 16(1), 1-24. 
Libaert, T. (2009). Planul de comunicare. Cum să-ți definești și să-ți organizezi strategia de comunicare (Communication Plan. How to Define and Organize Your Communication Strategy). Iași: Polirom.

Regester, M. \& Larkin, J. (2003). Managementul crizelor și al situațiilor de risc (Crisis and Risk Management). Bucharest: Comunicare.ro.

RMGC1. Community Development from Rosia Montana - Summary. Retrieved August 3, 2013, from http://en.rmgc.ro/rosia-montana-project/community/community-development.html.

RMGC2. Recea Neighborhood in Alba Iulia. Retrieved August 3, 2013, from http://en.rmgc.ro/rosia-montana-project/communitys/recea-neighbourhood-in-alba-iulia.html.

RMGC3. Environment. Retrieved August 4, 2013, from http://en.rmgc.ro/rosia-montana-project/environ ment.html.

O'Connor, A. (2005). Reputation Management. Heath, R. L. (Ed.), Encyclopaedia of Public Relations. Thousand Oaks, California: Sage Publications, Inc.

Oliver, S. (2009). Strategii de relații publice (Public Relations Strategies). Iași: Polirom.

Wolton, D. (2012). Despre comunicare (Penser la communication). Bucharest: Comunicare.ro. 